\title{
SENTIMENT ANALYSIS OF THE SYRIAN CONFLICT ON TWITTER
}

Danijela Lucić :: Josip Katalinić :: Tomislav Dokman

ORIGINAL SCIENTIFIC PAPER / DOI: 10.20901/ms.11.22.3 / SUBMITTED: 5.7.2019.

\begin{abstract}
Social media have become an important means of imposing ideas and interests in social conflicts. The Syrian conflict is analysed using sentiment analysis of tweets in order to establish how the sentiment shapes the modern political landscape and influences recipient knowledge. The importance of social networks and their potential in overthrowing regimes as well as in radicalization are highlighted. The authors suggest several stages that can be used for analysing tweets and how they impact the reader with selected narration. Sentiment analysis is used on a trained data set as a way to gain insight into tweets of different factions in the Syria conflict. Selected tweets on missile strikes were published on 14 April 2018 and the day after. The Twitter profiles of three different sides - pro-Assad, pro-West and antiAssad - were also analysed. The results show that there is a real battle on social media with the purpose of influencing human emotions.
\end{abstract}

\section{KEY WORDS}

$$
\text { SYRIA CONFLICT, ARAB SPRING, SYRIA MISSILE STRIKES, TWITTER, SENTIMENT ANALYSIS }
$$

Authors note

Danijela Lucić :: University of Zagreb, Faculty of Humanities and Social Science, Department of Sociology :: dalucic@ffzg.hr

Josip Katalinić :: University of Zagreb, Faculty of Humanities and Social Science, Department of Information and Communication Science :: josipkatalinicandroid@gmail.com Tomislav Dokman :: University of Zagreb, Faculty of Humanities and Social Science, Department of Information and Communication Science :: dokman.tomislav@gmail.com 


\section{INTRODUCTION}

The demonstrations that began in 2011 on the wings of the Arab Spring broke out in a brutal clash with more than half a million casualties. The geopolitical situation in Syria was more complex, especially with active involvement and participation of five nuclear powers: France, the United States, the United Kingdom, China and Russia. Neighbouring countries such as Turkey, Israel, Iran, Saudi Arabia and Iraq also played an important role in the fighting at the time and tried to achieve their security goals in Syria. Internal factors were also extremely complex, through divisions between ISIS, Kurd, AlQaeda and numerous other factions that controlled the Syrian population and directed it towards armed conflicts between the factions and/or the central government. The central government in Damascus had a favourable position because of the direct support of Russia and Iran, which enabled it to reach a military resolution of the violent conflict and reintegration of population. The Syrian conflict is highly publicized and the conflict of narratives shows great interest in shaping public opinion through the operations of influence. Johnson et al. (2017: 556) claim that platforms like Twitter "react quickly to events as they unfold and control the resulting discussion according to their views". While some authors highlight that social media are often used for spreading specific narratives to target audience (Garrett, 2019; Hellweg, 2011; Simons, 2016), Garcia (2013: 249) claims that "Twitter has become a reflection of the public agenda".

No matter what theory we find more convincing, it is undeniable that many factions fighting for geopolitical targets in the Syrian space also struggle within the media space and every incident has a potential to gain attention of the international community. Terrorist organizations are changing their names (Jones et al., 2018), clashing factions fake attacks (RT, 2018) and are using means that allow them to change images or put more pressure on the opposition. Numerous social networks, TV channels, bloggers and influential individuals create a paradigm of communication, from the above-mentioned content distribution channels to Twitter and beyond. High-volume and short messages called tweets can display up to 280 characters (Perez, 2018) and are suitable for short messaging and are able to set up multimedia content such as videos and images. The speed of Twitter news coverage allows saturation of media space by planned attack.

\section{THE ARAB SPRING}

A series of protests that began at the end of 2010 in Tunisia soon became a wave of revolutions that grew into a complex relationship of political regime change, military intervention, radicalization of society and civil war while resulting in a large number of civilian casualties. The Arab Spring soon spread from Tunisia through the influence of social networks, and gave rise to the cases of successful regime change in: Libya, Egypt and Yemen. The vacuum of power enabled many actors to take advantage of the situation and turn the revolution against minorities and other factions. The protests in Tunisia were of a socioeconomic character as youth unemployment was a burdening issue that reached 40\%. Therefore, on 17 December 2010, Mohamed Bouazizi, a young man with a university 
degree, due to the impossibility of employment, committed suicide by self-immolation in the city of Sid. After the incident of self-immolation, the protesters clashed with the police and a couple of protesters died (Raghavan, 2011). Thanks to Facebook, many call the revolution in Tunisia 'Facebook Revolution' because of the great influence this social network had on the political situation in the country, as well as on bringing the situation to a global context (Lotan et al., 2011; Wulf et al., 2013). Satellite channels like Al Jazeera began to take video clips that had been released and broadcast them to the wider audience. All their stories, fears, dissatisfaction and excitement became a real power after they began to appear on television (Delany, 2011). A similar situation took place in Egypt where, after thirty years of rule, Hosni Mubarak was overthrown, after only eighteen days of protest. In the first democratic presidential election, the Muslim Brotherhood took the lead with Mohammed Morsi, who assumed the role of President of Egypt. Such a situation did not last long, and after a year, with the help of a military coup, Abdel Fattah al-Sisi removed President of Egypt Morsi from power. Moreover, he forbade the Muslim Brotherhood from participating in political activities (Hove and Ndawana, 2017). The Arab Spring in Libya had particularly significant geopolitical implications for international actors involved in overthrowing of Muammar Gaddafi where the UN Security Council failed to establish a civil government after overthrowing the dictator. Libya is still extremely unstable with around 300 different military organizations colliding on a daily basis (el-Bijou, 2013). The protests in Yemen began in late January 2011 after citizens in the streets decided to support the revolution that took place in Tunisia and Egypt. The government responded to the protests using force, and on 18 March 2011, snipers killed more than fifty people in the capital city of Sanna. They tried to intimidate the public, but the opposite effect was achieved. The changes occurred, but the citizens were sceptical as the changes were a kind of rotation of people close to the previous regime. This movement led to a great social cleavage within the society, but also to the fragmentation of the Yemeni state. The localized struggles, involving both internal and external factors, with the aim to access resources and power, opened the door to a civil war that still lasts (Clausen, 2018; Fanack, 2017).

\section{THE SYRIAN CONFLICT OF NARRATIVES}

In 2014, Khaldoun Khashanah in his work The Syrian Crisis: a systematic framework stated that there was no framework for understanding the Syrian crisis. This is a valid statement even today as well as the one that indicates that the complexity of the Syria crisis comes from two simultaneous confluences - an ideological as well as geopolitical. The Syrian conflict, in addition to its military and political aspects, also has a major clash in the media space whose goal is influence on the ground. A media study published by the European Institute on Peace in 2015, titled Syria in Global Media 1 and subtitled Representation of Syria in international digital media and social media from March 2015 - September 2015 speaks in favour of the geopolitical game that is visible in the media too. The study attempts to answer a few questions: What is the media discourse of the international media and social media on Syria like during the time chosen for the study?; Who writes about Syria, and what, according to a country or a media outlet?; What are the main themes on Syria circulated in the international media? Which types of content concerning Syria circulate in 
the international social media? Do the international social media reflect the Syria-related content of the mainstream media outlets? The methodology behind the study includes analysis of digital and social media and eight top sources have been examined: Turkish Daily Sabah, Russian Sputnik International, Chinese Xinhua News, US The Washington Post, British BBC, Indian The Times of India, French France24 and VICE News whose headquarters are in New York, the United States. Two key findings on social media say that in "many cases there were small groups with clear political agendas posting content on Twitter or Facebook" and that social media "posts on Syria are challenging to track reliably due to a large amount of bots and ideological posting by different groups" (EIP, 2015).

Extremist groups are also operating in that space, many of which have been declared terrorist organizations such as ISIS, al-Nusra, al-Qaeda and several al-Qaeda-affiliated factions (Jones, 2018). Radicalization of ISIS and other terrorist groups on social networks is fuelling the issue in Europe and the world as a whole, as terrorists can now create combatants and potential terrorists without the need for crossing borders. Popular social platforms Twitter, Facebook and YouTube thus become a battlefield of ideologies. The narrative uses the focus on political and ideological goals, as well as emphasizing that men in the West cannot practice their faith in Islam by creating 'us against the whole world' mentality in the targeted population. The sense of manhood and adventure in jihad is explained through excitement and comparison with playing video games (Brown, 2018). Brutal videos with captives also play a role in radicalizing members of the group, as well as intimidating the enemy. The other great danger, apart from the social networks for radicalization, are terrorist returnees who, in organized cells, can influence their world viewers by transferring ideas and experiences from the battlefield to the civilian population. Abu Bakr al-Baghdadi, a so-called caliph who declared the death of the 1916 Skyes-Picot agreement that divided the region between the United Kingdom and France and has a major role in radicalization and the struggle of Islam in the Middle East. To the terrorism he replied by the statement that it was Allah's judgment, worship of Allah as he had ordered and the rejection of humiliation and subordination. Pro-West messages on social media clearly express attitudes towards democracy, the overthrow of Assad, and the establishment of parliamentary democracy, guided by the principles of Western democracies. West support is primarily directed to the Free Syrian Army (FSA), which acted as a coherent pro-West group at the beginning of the conflict. The military equipment, as well as the supply of modern military systems that have capacities comparable to the regime forces, is openly funded by the United States. Funding was directed to fighting the regime and to fight against Islamic extremists who came to Syria (Sanchez, 2018).

But as Ahad (2016: 25) said, apart from being a "theatre for great power political and military showdown", the Syrian war has also been an "object of international media competition" which can be partly seen from the way in which media in Syria are financed. Brownlee (2017) argues that even before the outbreak of the uprising of 2011, the Syrian media had a strong international development. She concludes that in the field of media development, a new modus operandi (bottom-up support) of the West, and the USA in particular, could be noticed. 
Sophie Eisentraut (2018), from the Finnish Institute of International Affairs' Global Security Research Programme describes in her blog this tangled Middle Eastern story that is taking place on Twitter too:

The stories and headlines promoted in pro-Kremlin Tweets are clearly aimed at increasing pressure on the Americans and their allies to abandon their engagement in Syria. Syria, these stories claim, is mostly restored to normality, suggesting that the only impediment to lasting peace is the continuing US military presence. One story recently pushed to the pro-Kremlin network's US audience claims that the Syrian peace process is essentially being stymied by the Americans, who harbour radical militants in their garrison at al-Tanf, from which jihadists then launch attacks.

\section{TWITTER'S NEW BATTLEGROUND}

It has been known that the role of the mass media in influencing people's perceptions and opinions is unquestionably important. With the technological and communication innovations, especially with the emergence of social media, this issue is even more noticeable. Social media are a "double-edged sword" as they can be used to both aid in manipulation as well as bring to light such manipulation (Simons, 2016: 5). Undeniably, the social media development and using social media as a means of information war are shaping the environment of conflicts, but also "magnify the importance of the psychological battle to the conflict outcome" (Karatzogianni, 2005: 189). This is especially important in the case of Syria conflict as it is shown in Kozman and Melki's (2018) study. They discuss the theory of the uses and gratifications in war and conflict using the Syrian conflict as a case study and the results show that among digital media, social media had the most important role.

One of such social media is Twitter. In 2018, this social network exceeded 335 million active users, which makes Twitter a significant and influential platform for radicalization and influence on political attitudes in general (Statista, 2018). Twitter's microblogging format allows up to 280 characters, where users enter their messages, which can be liked, commented and shared, thus allowing news to spread quickly. Spreading news is facilitated by "\#" (so-called hashtags) to mark certain news. From our point of view, we can interpret them as metadata related to the post. Followers can see posts from tracked profiles that appear in the news without the need to check \# characters and track them. Numerous political announcements by US President Donald Trump, enhanced the popularity of this social network. Trump's use of Twitter for political purposes provoked reactions from other powers, particularly in relation to Syria, where Russia explicitly stated that it would not engage in diplomacy via Twitter (Al Jazeera and News Agencies, 2018), but the media struggle was more than obvious. Even seven days before the Syria strikes of April 2018, US President Trump wrote on his Twitter profile

Russia vows to shoot down any and all missiles fired at Syria. Get ready Russia, because they will be coming, nice and new and "smart!" You shouldn't be partners with a Gas Killing Animal who kills his people and enjoys it! (Trump, 2018) 
This post was certainly very important for all later Twitter battles; especially those after the missile strikes against Syria had been started. After the US President Trump tweeted about the missile airstrikes launched by the USA, the UK and France on 14 April 2018, Russian president Vladimir Putin said that this was an "act of aggression" and that strike would "have a destructive effect on the entire system of international relations" (Roth and Ellis-Petersen, 2018). Beside the media answer, Russia also gave active military help to Assad's regime and the geopolitical battlefield spread beyond the virtual world of Twitter and other media as well.

Twitter news reach the public much earlier than it is communicated via official channels of the presidential office, which makes space for wrong messaging. On the other hand, radicalization through promotion of terrorism itself, especially within the population of ISIS foreign fighters (Klausen, 2015) and violent threats become a major problem for the platform. In the first six months of 2016, Twitter suspended 235,000 accounts for promotion of terrorism, adding that they had previously suspended 125,000 accounts for the same reason. Daily suspensions from 2015 are up 80\%, with increases during major terrorist attacks. The time of action for suspension was drastically reduced and cooperation with other social platforms was made to identify terrorist content (Woolf, 2018). In addition to extreme profiles that publicly call for violence and are being removed, a large number of accounts do not invoke violence or terrorism, but are spreading lies and half-truths in order to change the public's opinion on certain topics concerning the client. It is beyond any doubt that "Syria has become the most sophisticated battlefield in the world since 2011" (Zhou, 2019: 247) and these events surely influenced the opinions and emotions of many people around the world.

\section{RESEARCH DESIGN AND METHOD}

The attack on Syria by the United States, the United Kingdom and France that occurred on 14 April 2018 showed a drastic increase of 2000\% Russian troll's activity only a few hours after the attack. Their task was to spread disinformation about the attack on Syria by creating a new pro-Russian narrative. This narrative in coordination with social networks was later confirmed by Moscow's statements that Syria had shot down 71 out of 103 missiles (Read, 2018). The attack came as a reaction to a chemical attack on Douma, which was at the time under siege by government forces. Russia called the attack staged and claimed that it had been organized on social networks by White Helmets (Wintour, 2018). These events provoked numerous reactions and activities on social networks, and this paper attempts to answer the question as to how the conflict was manifested on the social network Twitter and to identify the goals and the consequences of this Twitter conflict.

In an effort to answer the above research questions, numerous tweets were collected and sentiment analysis was conducted. To understand the collected tweets, an important part is sentiment analysis that, through contextual mining of the text, identifies subjective information in the original material and helps us to understand the reasoning through 
the monitoring of data. Sentiment analysis is intended to analyse "people's opinions, sentiments, evaluations, appraisals, attitudes, and emotions towards entities such as products, services, organizations, individuals, issues, events, topics, and their attributes" (Liu, 2012: 7). Pang and Lee (2008) quote several different terms used as synonyms for sentiment analysis such as 'opinion mining', that is frequently used, and some others which are not so common such as 'subjectivity analysis', 'review mining', 'appraisal extraction', 'affective computing'. Through the analysis of messages we can get basic information about sentiment that can be positive, negative and neutral as well as its subjectivity with respect to the trained data set (Gupta, 2018).

There are lots of software solutions to conduct sentiment analysis and different methods for maximizing sampling efficiency (Taddy, 2013: 415). As Thelwall (2017: 545) stated, sentiment analysis research was originally driven by a commercial need but today it is used in many different fields such as marketing, economics, healthcare, education, politics and others. For example, Diakopolous and Shamma (2010) portrayed the 2008 presidential debate between Barrack Obama and John McCain using aggregated Twitter sentiment. Stieglitz and Dang-Xuan (2013) were focused in their research on sentiment occurring in social media and how it is associated with a user's behaviour in terms of information sharing or retweeting ${ }^{1}$ if we talk about Twitter. Taddy (2013) used this analysis for evaluating Twitter posts as positive, negative, or neutral in terms of sentiments directed toward particular U.S. politicians. It is not unusual that sentiment analysis is used for predicting the election results or discussing the potentiality of predicting elections via social media and sentiment analysis (Ceron et al., 2013; Kassraie et al., 2017; Metaxas et al. 2011; Ramteke et al., 2016; Salunkhe and Deshmukh, 2017; Sharma and Moh, 2016; Tumasjan et al., 2010). Most of the authors listed above talk about sentiment analysis benefits, but Kennedy (2012) pointed to difficulties and critical perspectives on this analysis, especially the type which relies on a machine rather than on human analysis. When it comes to machine-mediated sentiment analysis, there are many different sentiment applications, software lexical solutions used for sentiment analysis. Some of them are SentiWordNet (Baccianella et al., 2010); SenticNet (Cambria et al., 2014), and SentiStrength (Thelwall, 2017). Kabakus and Kara (2018) also cited AFFIN and NoSlang.com but they are dominantly directed to Twitter sentiment analyser approach based on linguistic techniques called TwitterSentiDetector. For the purpose of this research, Python as well as Phython's library TextBlob are used.

\section{SAMPLE AND PROCESS OF DATA COLLECTING}

If we look at the tweets published while the attack was happening, there were three distinct camps: pro-Assad, anti-Assad and pro-West. Key words selected for research are those that describe the attack and appear within the published tweets such as: 'explosion', 'strike', 'hit', 'attack', 'defence', 'Syria' and 'missile'. All of these tweets were collected during

\footnotetext{
$\overline{1 \text { Unlike }}$ some other social media (Facebook, Instagram, etc.) sharing information on Twitter is done through so-called retweeting where users do repost or forward a message which is posted by another user. Retweet is done through easily accessible option which can be recognized by means of the remark 'Retweeted' and @ sign in front of the username whose post is shared.
} 
the 14 April 2018 attacks, as well as the day after the attacks, allowing commenting to all non-real time users that happened to comment events of 14 April during a coalition attack. Five chosen profiles are anonymised and, for the purposes of this paper, we call them Profile 1, Profile 2, Profile 3, Profile 4 and Profile 5. The initial profiles chosen to be quantified and measured by sentiment analysis for the West are Profile 2, Profile 3 and Profile 4, for pro-Assad Profile 1, while for anti-Assad Profile 5. The profiles are selected on the basis of their reporting bias that is displayed on the website 'syria.liveuamap' via random selection. Collecting tweets is conducted through three steps that follow a linear sequence of actions. In the first step, Twitter $\mathrm{API}^{2}$ is used as a landing point for connecting to Twitter and its interface. Once we connect to Twitter, we continue to the second step through the Python programming language where we use Tweepy to consume Twitter APIs by defining extraction rules, such as: key words, profiles, date, place, language and so on. In the second step, apart from the rules of extraction, a sentiment analysis is also performed in Python using a TextBlob, library for textual data or natural language processing tool that allows sentiment analysis with polarity and subjectivity analysis for collected tweets based on a trained data set. In the last third step, we are doing visualization of the sentiment analysis data by storing data as .csv which is then converted to .xlsx using the Excel program that allows visual representation through charts, tables, and the like.

For polarity, a set of data from 1000 positive and 1000 negatively processed reviews was used. In the five-star system (or a compatible number system), we labelled three and a half stars or more as positive polarities, while two stars and less were considered negative polarities. With the four-star system (or compatible number system), we marked three stars or more as positive, while one and a half or fewer were considered negative. The letter system is quantified in a way that $B$ or above is considered positive, while $C$ or below is considered negative. The obtained points are between -1 and 1 , where 1 is super happy and -1 is horrible. For example, 'The weather is beautiful today in Zagreb with many wonderful people.' would have a positive polarity of 0.7833 , while 'This is a violent and hateful sentence.' would return a negative polarity of -0.8 . In these examples, we can clearly see that certain words based on a trained data set classify sentences as positive or negative. Therefore, words like 'beautiful' and 'wonderful' affect positively polarization rating, while words such as 'violent' and 'hateful' lower the polarity rating.

For subjectivity, 5000 subjective and 5000 objective sentences were used, assuming that all of the clips from the Rotten Tomatoes page are subjective, and all the sentences from the IMDb are objective. The assumption was made with the knowledge that the reviews on Rotten Tomatoes were written by users, while the IMDb reviews were written by professional reviewers. A potential problem of this approach consists in the fact that summaries may occasionally contain subjective sentences that are mistakenly labelled as objective, which may be the case with the use of sarcasm within reviews. The points of subjectivity are grades between 0 and 1, where 0 is the fact, while 1 is extremely

\footnotetext{
$\overline{2}$ As it is stated on Twitter Help Center, Twitter API (application programming interfaces) is the way computer programs 'talk' to each other, so that they can request and deliver information. This is done by allowing a software application to call what is known as an endpoint: an address that corresponds with a specific type of information we provide (endpoints are generally unique like phone numbers). For more on Twitter API, see: https://help.twitter.com/en/rules-and-policies/twitter-api
} 
subjective. For example 'I can fly and shoot laser.' returns 1 which is extremely subjective, while the sentence 'In 2016, the U.S. Department of Defense purchased 149 Tomahawk Block IV missiles for $\$ 202.3$ million' returns 0 which marks it as a fact. Here we also see that certain words like 'fly' and 'laser' raise subjectivity, while words such as 'Department' and 'Tomahawk' reduce subjectivity.

In short, while polarity measures the level of emotion in a text and the relation between rational and emotional statements, subjectivity expresses some personal beliefs, feelings or views.

\section{RESULTS}

The collected data are based on five Twitter profiles that served as the starting point for collecting tweets, as well as from the accounts that follow the profiles. The affiliations are divided into three groups: pro-Assad, anti-Assad and pro-West, where for pro-Assad Profile 1 is selected, for anti-Assad Profile 5, while for the West: Profile 2, Profile 3 and Profile 4 are chosen. This random selection described in the text above is the reason why there are differences in their Tweet account as well as followers/following account. The results show that, compared to other profiles, Profile 3 has the fewest tweets and is the least followed among the profiles, but at the same time it has the greatest number of followers. By far the largest number of tweets belongs to the anti-Assad Twitter user Profile 5. Yet, it should be emphasized that most of its tweets/posts are retweeted or shared from other Twitter accounts. Pro-West Profile 2 is pretty active as well, but it also mainly shares others posts and news.

Table 1. Processed starting profiles

\begin{tabular}{lllll} 
Handle & Following & Followers & Tweets & Affiliation \\
\hline Profile 1 & 2792 & 39300 & 6338 & pro-Assad \\
Profile 2 & 1151 & 14500 & 30400 & pro-West \\
Profile 3 & 770 & 43600 & 2700 & pro-West \\
Profile 4 & 734 & 10400 & 4109 & pro-West \\
Profile 5 & 3100 & 1257 & 122000 & anti-Assad \\
TOTAL & 8547 & 109057 & 165547 & \\
\hline
\end{tabular}

Extracted tweets vary considerably in their quantities and clearly indicate that they are not proportional to the total of all the tweets of a particular profile, nor to the number of followers. Certain Twitter profiles attract profiles that are much more active on social networks and convey news that are similar to the profile. After collecting tweets, we conducted a sentiment analysis in which tweets were processed through polarity and subjectivity. 
Table 2. Processed following sentiment

\begin{tabular}{lllll} 
Handle & Following Tweets & Polarity & Subjectivity & Affiliation \\
Profile 1 & 6559 & 0 & 0,075 & pro-Assad \\
Profile 2 & 699 & $-0,1875$ & 0,1875 & pro-West \\
Profile 3 & 2308 & 0,25 & 0,5 & pro-West \\
Profile 4 & 618 & 0,0167 & 0,2 & pro-West \\
Profile 5 & 1378 & $-0,05$ & 0,1 & anti-Assad \\
TOTAL & 11564 & 0,029 & 1,063 & \\
\hline
\end{tabular}

In Table 2, the processed data are described and the results based on a trained data set used to classify sentiment. There were a total of 11,564 tweets containing pre-defined key words, as well as the release date associated with the missile attack. We can clearly see that pro-Assad tweets are the most numerous, which reaches the same number of people as the Pentagon warns, pointing out that the activities of Russian trolls during the attack increased by $2000 \%$. For these activities, Kremlin is directly accused of financing and supporting the operations of influence through the 'troll factory' in Sankt Petersburg (Nimmo, 2018). For other users, the number of tweets is considerably smaller and there are significant differences in polarity and subjectivity between different affiliations. Most of the profiles are within neutral polarity, while pro-Western profiles are positive since the coalition launched an attack. The pattern for subjectivity where pro-Western profiles report with the greatest subjectivity is similar. Here we can notice that, although the proAssad polarity is neutral, subjectivity is slightly higher, which shows that the activity of the trolls is with neutral polarity and light subjectivity that can influence the public opinion through the quantity of false information. It is interesting to see that the highest level of polarity as well as subjectivity can be assigned to Profile 3 . His specific discourse could be characterized as literary as this user is also a writer who often uses words that affect human emotions.

Tweets are based on previous profiles and there are 18,126 tweets matching the defined rules. There is a trend where pro-Assad Twitter profiles follow the profiles that write a lot more on the attack than pro-West or anti-Assad profiles. The difference is disproportionately large compared to the stable and proportionate tweets of other profiles. The behaviour pattern is identical and shows the increased activity of the trolls, which were activated during the attack as well as immediately after the attack.

Table 3 represents sentiment analysis of collected tweets for people who follow selected Twitter profiles. The largest number of tweets collected is again on the side of the pro-Assad trolls who overwhelmed the social network through their posting, and thus created a narrative. Polarity of pro-Assad tweets is positive and slightly subjective, while Profile 2 followers have by far more positive polarity and high subjectivity; the Profile 4 reporter in one British media outlet has a high negative polarity and high subjectivity, since he is also a Syrian citizen and tells Syria's side of the story. It is interesting that Profile 5 as well as his followers have a very low level of subjectivity, but it is probably related 
to the fact outlined above that Profile 5 is a user whose posts are dominantly shared or retweeted. In other words, he mainly broadcasts news and facts from other media.

Table 3. Processed followers' sentiment

\begin{tabular}{lllll} 
Handle & Followers Tweets & Polarity & Subjectivity & Affiliation \\
Profile 1 & 11893 & 0,1 & 0,15 & pro-Assad \\
Profile 2 & 1770 & 0,25 & 0,35 & pro-West \\
Profile 3 & 995 & 0 & 0 & pro-West \\
Profile 4 & 1881 & $-0,35$ & 0,625 & pro-West \\
Profile 5 & 1187 & 0 & 0,0833 & anti-Assad \\
TOTAL & 18126 & 0 & 1,208 & \\
\hline
\end{tabular}

Subsequently, six months later Pro-Assad Twitter profile called Profile 1 had been suspended due to Twitter suspension policy. The exact reason for the suspension of the profile whose followers had been the most active of all is unknown. Nevertheless, it is known that there are three common reasons for suspension in general: abusive behaviour, which means sending threats to others and similar; an account that has been hacked or compromised; and an account that is spamming others. Probably, Profile 1 followers' activity is the main reason why this suspension caused Twitter discussions on righteousness of the act. On 27 February 2019, one post on another pro-Assad Twitter profile appeared where the suspension of Profile 1 had been commented. The position was expressed that this was a wrong decision as well as a belief that many others would agree that Profile 1 account should be reinstated. Some commentators agreed with this but some expressed the pleasure for removing this profile from Twitter. On the other hand, all remaining analysed profiles are still active. Pro-West Twitter users Profile 2, Profile 3 and Profile 4 have increased the number of followers. Profile 2 has almost five thousand followers more than on 14 and 15 May 2018, Profile 3 has about two thousand and Profile 4 about three thousand followers more. Anti-Assad Profile 5 is also still active but the number of its Twitter followers had decreased by half.

If we take a look at the current political and geopolitical situation in Syria and the Middle East in general, as well as possible scenarios for the future, the situation does not look optimistic. The situation in Syria today is still tense though it may not be at the same level as it was a few months ago, especially among the biggest actors, Washington and Moscow. Nonetheless, this does not mean that the same situation will not be repeated in the future or that it will not be even worse. Most but not all of US troops have left the war zone in Syria; ISIS and its caliphate idea have been defeated but a threat from many local jihadist groups is still alive; Russia is still giving strong support to President Assad's regime; the situation in the north-western Syrian province of Idlib is escalating, especially between Syrian and Turkish forces; the Turkish alliance with Russia is no longer as stable as it was in September 2018 and in the months that followed the Sochi agreement. In addition to all the above mentioned, tensions between the USA and Iran have been 
escalating. The Twitter battlefield certainly will not rest. Moreover, it may be even more intense than it was before.

\section{CONCLUSION}

Observing the paradigm of communicating on Twitter tells us that a certain side in conflicts has been actively promoting its interests through Twitter. We can even talk about information operations on social media, whose platform is adequate for influencing the recipients' view of a specific topic as well as public knowledge. Information operation aims "to influence an adversary or potential adversary in support of political and military objectives by undermining his will, cohesion, decision-making ability, through affecting his information" (MOD UK, 2002: 2-1). In this sense, social media environment presents a new and specific challenge which is also confirmed by the Syrian case. The April missile attack shows a real battle on social networks, a battle aimed at attacking human emotions. By quantifying the collected tweets, we noticed that on one tweet that falls under antiAssad or pro-West, there is an average of six pro-Assad tweets. Such a big difference points to institutionalized and sponsored posting through carefully designed campaigns targeted at spreading disinformation. By analysing Twitter accounts, we noted that proAssad accounts attract the largest number of followers-They publish on average ten times more than other accounts. Their polarity is slightly positive, indicating the postings of happier content, their subjectivity is also slightly positive, which means that we find halftruths in a large number.

Such anti-social practice, as trolling for sure is, could thus transform a particular event into a narrative that suits them at a given moment, but also exacerbate or even cause very tense social relations. Impact on emotions by using targeted words that have higher polarity and subjectivity directs audiences to the desired behaviour or perceptions. The message comes to the user through a large number of posts with the help of a Twitter platform that facilitates short postings with a large number of reply options. Automatic publishing, as well as trained bots, allow for constant narration, while trolls are particularly suitable for real-time notifications, since responses need to be formatted on the basis of the input that is taking place. The trend of anti-social practice such as trolling for sure is, may be slowed down by legal frameworks, where parties will be punished for misrepresentation, but this will not prevent third parties from entering the media space and spreading their narrative. Critical thinking and narrative research requires a lot of time, and the best solution for the mentioned problem is free and independent journalism that citizens trust. Media consumers should also be aware that all media channels, especially social media, are playing a very important role and that they have become an extensive battlefield which is hard to control. Every second in the world, there are millions of deliberate, rogue, deceptive, malicious and aforethought attempts intended to influence people's opinions and emotions. The Syrian case is very illustrative in this respect. The results of sentiment analysis presented above indicates that the struggle for human hearts and minds will continue to take place in this very broad and very auspicious field called social media. 


\section{References}

>Ahad, Wassem (2016) Syrian War and Media Politics: Priming, Framing and Agenda-Setting. E-Journal of Social and Legal Studies 2 (1): 25-32.

$>$ Al Jazeera and News Agencies (2018) Kremlin to Trump: We don't engage in Twitter diplomacy. https://bit.ly/2EGxCLw (13.10.2018).

>Baccianella, Stefano, Esuli, Stefano and Sebastiani, Fabrizio (2010) Sentiwordnet 3.0: An Enhanced Lexical Resource for Sentiment Analysis and Opinion Mining, pp. 2200-2204 in Calzolari, Nicoletta, Chourki, Khalid, Maegaard, Bente, Mariani, Joseph, Odijk, Jan, Piperidis, Stelios, Rosner, Mike and Tapias, Daniel (eds.) Proceedings of the Seventh International Conference on Language Resources and Evaluation Valletta, Malta, 17-23 May 2010. Valletta: European Language Resources Association. >Brown, Katherine (2018) This is how Islamist radicalisation actually happens. https://www. independent.co.uk/voices/manchester-attack-isis-al-qaeda-radicalisation-risk-factors-a7753451. html (05.10.2018).

>Brownlee, Billie Jeanne (2017) Media development in Syria: the Janus-faced nature of foreign aid assistance. Third World Quarterly 38 (10): 2276-2294. DOI: 10.1080/01436597.2017.1333420 $>$ Cambria, Erik, Olsher, Daniel and Dheeraj, Rajagopal (2014) SenticNet3: a common and common-senseknowledge base for cognition-driven sentiment analysis, pp. 1515-1521 in Proceedings of The Twenty Eighth AAAI Conference on Artificial Intelligence, Québec City, Québec, Canada, 27-31 July 2014. Palo Alto, California: The AAAI Press.

>Ceron, Andrea, Curini, Luigi, lacus, Stefano Maria and Porro, Giuseppe (2014) Every tweet counts? How sentiment analysis of social media can improve our knowledge of citizens' political preferences with an application to Italy and France. New Media and Society 16 (2): 340-358. DOI: $10.1177 / 1461444813480466$

$>$ Clausen, Maria-Louise (2018) Competing for Control over the State: The Case of Yemen. Small Wars \& Insurgencies 29 (3): 560-578. DOI: 10.1080/09592318.2018.1455792

>Delany, Collin (2011) How Social Media Accelerated Tunisia's Revolution: An Inside View.http:// www.epolitics.com/2011/02/10/how-social-media-accelerated-tunisias-revolution-an-inside-view/ (26.09.2018).

>Diakopolous, Nicholas A. and Shamma, David A. (2010) Characterizing Debate Performance via Aggregated Twitter Sentiment in Proceedings of the SIGCHI Conference on Human Factors in Computing Systems, Atlanta, Georgia, USA, 10-15 April 2010. New York: ACM.>EIP (The European Institute on Peace) (2015) Syria in the Global Media 1. March 2015 - September 2015. http://eip.org/ en/news-events/warpeace-reporting-syria-global-media (02. 10.2018).

>Eisentraut, Sophie (2018) Russia's Propaganda War about Syria: How Pro-Kremlin Twitter Accounts Manipulate the West. https://isnblog.ethz.ch/social-media/russias-propaganda-war-about-syriahow-pro-kremlin-twitter-accounts-manipulate-the-west (05.10.2018).

>el-Bijou, Lamin (2013) Arab uprising: Country by country - Libya. https://www.bbc.com/news/ world-12482311 (01.10.2018).

>Fanack.com (2017) Yemen's Arab Spring. https://fanack.com/yemen/history-past-to-present/ yemens-arab-spring/ (01.10.2018).

>Garcia, Raquel Rubio (2014) Twitter y la teoría de la Agenda $\neg$ Setting: mensajes de la opinión pública digital. Estudios sobre el Mensaje Periodístico 20 (1): 249-264. http://dx.doi.org/10.5209/ rev_ESMP.2014.v20.n1.45230

$>$ Garett, Kelly R. (2019) Social media's contribution to political misperceptions in U.S. Presidential elections. PLoS One 14(3): e0213500. doi:10.1371/journal.pone.0213500. https://doi.org/10.1371/ journal.pone.0213500 >Gupta, Shashanka (2018) Sentiment Analysis: Concept, Analysis and Applications. https:// towardsdatascience.com/sentiment-analysis-concept-analysis-and-applications-6c94d6f58c17 (16.09.2018).

>Hellweg, Annie (2011) Social Media Sites of Politicians Influence Their Perception by Constituents. The Elon Journal of Undergraduate Research in Communications 2 (1): 22-36. 
$>$ Hove, Mediel and Ndawana, Enock (2017) Regime-change agenda: the Egyptian experience from 2011 to 2015. Contemporary Arab Affairs 10 (1): 32-50. DOI: 10.1080/17550912.2017.1279386 >Johnson Kristen, Jin Di and Goldwasser, Dan (2017) Modelling of Political Discourse Framing on Twitter, pp. 556-559 in Proceedings of 11th International AAAI Conference on Web and Social Media (ICWSM 2017), Montreal, Quebec, Canada, 15 - 18 May 2017. Palo Alto, California: The AAAI Press. >Jones, Seth G (2018) Al-Qaeda's Quagmire in Syria. Survival 60 (5): 181-198. DOI: 10.1080/00396338.2018.1518381

>Jones, Bryony; Ward Clarissa and Abdelaiz, Salma (2018) Al-Nusra rebranding: New name, same aim? What you need to know. https://edition.cnn.com/2016/08/01/middleeast/al-nusra-rebrandingwhat-you-need-to-know/index.html (26.09.2018).

>Kabakus, Abdullah Talha and Kara, Resul (2018) TwitterSentiDetector: a domain-independent Twitter sentiment analyser. INFOR: Information Systems and Operational Research 56 (2): 137-162. DOI: 10.1080/03155986.2017.1340797

>Karatzogianni, Athina (2005) The politics of cyberconflict: ethnoreligious conflicts in computer mediated environments. PhD Thesis, University of Nottingham, UK.

>Kassraie, Parnian, Modirshanechi, Alireza and Aghajan, Hamid K (2017) Election Vote Share Prediction using a Sentiment-based Fusion of Twitter Data with Google Trends and Online Polls, pp. 363-370 in Bernardino, Jorge, Quix, Cristoph and Filipe, Joaquim (eds.) Proceedings of the 6th International Conference on Data Science, Technology and Applications (DATA 2017) Madrid, Spain, 2426 July 2017. Setúbal, Portugal: SciTePress.

>Kennedy, Helen (2012) Perspectives on Sentiment Analysis. Journal of Broadcasting \& Electronic Media 56 (4): 435-450. DOI: 10.1080/08838151.2012.732141

>Khashanah, Khaldoun (2014) The Syrian Crisis: a systemic framework. Contemporary Arab Affairs 7 (1): 1-21. https://doi.org/10.1080/17550912.2014.881006

$>$ Klausen, Jytte (2015) Tweeting the Jihad: Social Media Networks of Western Foreign Fighters in Syria and Iraq. Studies in Conflict \& Terrorism 38 (1): 1-22. DOI: 10.1080/1057610X.2014.974948

$>$ Kozman, Claudia and Melki, Jad (2018) News Media Uses During War. Journalism Studies 19 (10): 1466-1488. DOI: 10.1080/1461670X.2017.1279564

>Liu, Bing (2012) Sentiment analysis and opinion mining. New York: Morgan Claypool.

>Lotan, Gilad, Graeff, Erhardt, Ananny, Mike, Gaffney, Devin, Pearce, lan and Boyd, Danah (2011) The Revolutions Were Tweeted: Information Flows During the 2011 Tunisian and Egyptian Revolutions. International Journal of Communication 5: 1375-1405.

$>$ Metaxas, Panagiotis Takis, Mustafaraj, Eni and Gayo-Avello, Daniel (2011) How (not) to predict elections, pp. 165-171 in Third Int'I Conference on Privacy, Security, Risk and Trust (PASSAT), 9-11 October 2011. Boston, MA.

>MOD UK (Ministry of Defence) (2002) Information Operation. Joint Warfare Publication 3-80. London: MOD.

>Nimmo, Ben (2018) \#TrollTracker: 2000\% More Russian Trolls on Syria Strikes? https://bit.ly/2KelJQX (18.10.2018).

$>$ Pang, Bo and Lee, Lillian (2008) Opinion mining and sentiment analysis. Foundations and Trends in Information Retrieval 2 (1-2): 1-135.

$>$ Perez, Sarah (2018) Twitter's doubling of character count from 140 to 280 had little impact on length of tweets. https://tcrn.ch/2Nct1KC (02.05.2019).

$>$ Raghavan, Sudarsan (2011) A lost generation of young people of Tunisia discuss grievances

that led to their revolution. https://wapo.st/2X1OqWA (28.09.2018).

$>$ Ramteke Jyoti, Samarth Shah, Godhia Darshan, Shaikh Aadil (2016) Election result prediction using Twitter sentiment analysis, pp. 1-5 in International Conference on Inventive Computation Technologies (ICICT). Coimbatore, India, 26-27 August, 2016,

$>$ Read, Carly (2018) Syria attack: Russian trolls flood internet hours after bombing. https://bit. ly/2RDQqDI (16.10.2018). 
$>$ Roth, Andrew and Ellis-Petersen, Hannah (2018) Vladimir Putin calls US-led Syria strikes an 'act of aggression'. The Guardian. https://www.theguardian.com/world/2018/apr/14/insulting-russiafurious-over-syria-attacks-as-politician-likens-trump-to-hitler (19.10.2018).

$>$ RT (2018) 'Foreign specialists' may stage chemical attack in Syria in 2 days to frame Assad Russian MoD. https://www.rt.com/news/436876-idlib-fake-chemical-attack/ (26.09.2018). $>$ Salunkhe, Pritee and Deshmukh Sachin (2017) Twitter Based Election Prediction and Analysis. International Research Journal of Engineering and Technology (IRJET) 4 (10): 539-544.

>Sanchez, Raf (2018) Syria: US clears way for Americans to start donating money to rebels. https:// bit.ly/2xbwj6h (10.10.2018).

>Sharma, Parul and Moh Teng-Sheng (2016) Election result prediction using Twitter sentiment analysis, pp. 1966-1971 in Proceedings of IEEE International Conference on Big Data, Washington DC, USA, 5-8 December 2016. Washington: IEEE Publisher.

>Simons, Greg (2016) News and Syria: Creating key media moments in the conflict. Cogent Social Science 2: 1170583. https://doi.org/10.1080/23311886.2016.1170583

>Statista (2018) Number of monthly active Twitter users worldwide from 1st quarter 2010 to 2nd quarter 2018 (in millions). https://www.statista.com/statistics/282087/number-of-monthly-activetwitter-users/ (13.10.2018).

>Stieglitz, Stefan and Dang-Xuan, Linh (2013) Emotions and Information Diffusion in Social MediaSentiment of Microblogs and Sharing Behavior. Journal of Management Information Systems 29 (4): 217-248. DOI: 10.2753/MIS0742-1222290408

$>$ Taddy, Matt (2013) Measuring Political Sentiment on Twitter: Factor Optimal Design for Multinomial Inverse Regression. Technometrics 55(4): 415-425. DOI: 10.1080/00401706.2013.778791 >Thelwall, Mike (2017) Sentiment Analysis, pp. 545-556 in Sloan Luke and Quan-Hasse Anabel (eds.) The SAGE Handbook of Social Media Research Methods. LA, London, New Delhi, Singapore, Washington DC, Melbourne: SAGE Publications Ltd.

>Trump, Donald [realDonaldTrump] (11 April 2018) Russia vows to shoot down... [Tweet]. https:// twitter.com/realdonaldtrump/status/984022625440747520?lang=hr (13.10.2018)

>Tumasjan, Andranik, Sprenger, Timm O, Sandner, Philipp G and Welpe, Isabell M (2011) Election forecasts with Twitter: How 140 characters reflect the political landscape. Social Sicence Computer Review 29 (4): 402-418. https://doi.org/10.1177/0894439310386557

$>$ Wintour, Patrick (2018) 'Obscene masquerade': Russia criticised over Douma chemical attack denial. https://bit.ly/2JzscF2 (16.10.2018)

$>$ Woolf, Nicky (2018) Twitter suspends 235,000 accounts in six months for promoting terrorism. https://bit.ly/2bBnYgk (13.10.2018).

>Wulf, Volker, Misaki, Kaoru, Atam Meryem, Randall, David and Rohde, Markus (2013) 'On the ground' in Sidi Bouzid: Investigating social media use during the Tunisian revolution, pp. 1409-1418 in Proceedings of the 2013 Conference on Computer Supported Cooperative Work, San Antonio, Texas, USA, 23-27 February 2013. New York: ACM.

>Zhou, Yimin (2019) A Double-Edged Sword: Russia's Hybrid Warfare in Syria. Asian Journal of Middle Eastern and Islamic Studies 13 (2): 246-261. DOI: 10.1080/25765949.2019.1605570 


\section{ANALIZA SENTIMENTA SIRIJSKOG SUKOBA NA TWITTERU}

\section{Danijela Lucić :: Josip Katalinić :: Tomislav Dokman}

SAŽETAK Društveni mediji postali su bitna platforma za širenje ideja i interesa u društvenim sukobima. Za analizu sirijskog sukoba korištena je analiza sentimenta, kako bi se shvatilo na koji način sentiment oblikuje aktualno političko okruženje i utječe na znanje recipijenta. Rad ukazuje na važnost društvenih mreža, ali i na njihov potencijal u svrgavanju režima, kao i na sam proces radikalizacije. Autori predlažu nekoliko faza koje se mogu koristiti u analizi tweetova. Analiza sentimenta je korištena na treniranom skupu podataka kako bi se dobio uvid u tweetove različitih frakcija sirijskog sukoba. Odabrani tweetovi odnose se na raketni napadom 14. travnja 2018., kao i na dan nakon napada, 15. travnja 2018. Analizirani Twitter profili uključuju tri različite strane: pro-Assad, pro-Zapad i anti-Assad. Rezultati pokazuju da postoji stvarni sukob u društvenim medijima s ciljem utjecanja na ljudske emocije.

KLJUČNE RIJEČI

SIRIJSKI SUKOB, ARAPSKO PROLJEĆE, NAPAD NA SIRIJU, TWITTER, ANALIZA SENTIMENTA

Bilješka o autorima

Danijela Lucić :: Filozofski fakultet Sveučilišta u Zagrebu, Odsjek za sociologiju :: dalucic@ffzg.hr

Josip Katalinić :: Filozofski fakultet Sveučilišta u Zagrebu, Odsjek za informacijske i komunikacijske znanosti :: josipkatalinicandroid@gmail.com

Tomislav Dokman :: Filozofski fakultet Sveučilišta u Zagrebu, Odsjek za informacijske i komunikacijske znanosti :: dokman.tomislav@gmail.com 